\title{
Particularities of the Psychoanalytical Clinic of Aging: Construction of Clinical Cases
}

\author{
José Maurício da Silva1, Jacqueline de Oliveira Moreira ${ }^{2}$ \\ ${ }^{1}$ Santo Agostinho High School, Contagem, Minas Gerais, Brasil \\ ${ }^{2}$ Postgraduate Program, Pontifical Catholic University, Belo Horizonte, Minas Gerais, Brasil \\ Email: mauricio@agostinianos.org.br, jackdrawin@yahoo.com.br
}

Received 5 May 2016; accepted 19 June 2016; published 22 June 2016

Copyright (C) 2016 by authors and Scientific Research Publishing Inc.

This work is licensed under the Creative Commons Attribution International License (CC BY). http://creativecommons.org/licenses/by/4.0/

(c) (i) Open Access

\begin{abstract}
This paper proposes to think the psychoanalytical clinic of aging as moved by challenges brought about by the considerable increase in the number of elderly people nowadays. By questioning the role of psychoanalysis in culture and supported by clinic experience, we think about the psychoanalytical clinic of aging while including interdisciplinary contributions and interventions. This approach defends sublimation as a means of sustaining the wish and, above all, as a means of transformation provided by social bonds, aiming to put the subject as the leader of his own history and assuming that investment is what upholds existence. There is no age for desire. Through this principle, one must "bet on life" even when the body becomes "an arena for diseases", always pointing towards death. Thus, psychoanalysis summons "the subject" to the hearing and remembering which enable his/her own histories and reconcile him/her with the legitimacy of his/her own wish.
\end{abstract}

Keywords

Aging, Psychoanalytical Clinic, Sublimation

\section{Introduction}

This paper is a result of several years of clinic experience with elderly people. Several reasons led us into this type of work. Among them, we can highlight the ageing of the world population and, particularly, by gaining increased longevity, the elderly have gained a greater visibility as well as demands arising from such social category. Another reason is the lack of psychoanalytical productions, i.e., the shortcoming of literature approaching ageing issue. These needs can be associated with prejudice towards the elderly such as linking them to senescence, unproductivity or inability to change. Thus, this study believes in the elderly person as a subject; one who speaks and by speaking he/she produces meanings for his/her own history. Thereby he/she implicates as a subject in his 
own life, actions and, eventually, in his/her own wish. Since it is a psychoanalytical research, our perspective relies on listening to the subject of the unconscious.

\section{Premises}

We can start this reflection by asking, "What is the sense in pondering a psychoanalytical clinic of aging? What drives us? Reality is challenging. According to U.N. reports, in 2050, for the first time in history, there will be more elderly people than children under 15 years old. In 2012, 810 million people aged 60 and over accounted for $11.5 \%$ of the world's population. It is estimated that this number will surpass one billion in less than ten years; and, in 2050, it will reach an average two billion people, that is, $22 \%$ of the global population. And Berquó (1996) estimated that, by around 2025, the elderly population in Brazil will exceed 30 million people.

Such scenario has given greater visibility to the elderly and thus, created demands which have brought up the question: how do psychoanalytical concepts respond to this new situation? How can psychoanalysis contribute to comprehending the aging process? We understand that psychoanalysis allows for listening, provides a space where an elder speaks, he/she is not spoken about, an instance in which he/she is summoned and involved into constructing his/her singularity.

We have noticed that a major demand presented by several seniors is a sense of meaninglessness which is expressed in questions such as, “I am 70 years' old; what now? What do I do?

Facing these queries, we searched for some guidelines in the Freudian papers concerning techniques. In "Basic tenets of psychoanalysis” ([1913]/2010), Freud reveals to us:

I already emphasize that it is not the fruit of speculation, but of experience, and, thus, it is incomplete as a theory. By means of its own inquiries, each one can persuade oneself of the correctness or incorrectness on the thesis within it, and contribute to its development (Freud, [1913]/2010: p. 269).

It is undeniable that, within Freud's works, we will find texts pointing to difficulties presented by analysis with the elderly (The psychoanalytical method, 1904/1996a; On psychotherapy, 1905/1996b; Lines of advance in psychoanalytic therapy, 1919/1996c, and Analysis terminable and interminable, 1937/1996d). Bearing this difficulty in mind, we believe, as Mucida (2006), that psychoanalysis "is a tool available to those who suffer and want to build up knowledge on the basis of this suffering. Such offer, which opens itself as a treatment for the real-running counter to what is offered by the market, touches that which is most singular within each subject, by giving rise to another type of demand anchored in (the) wish.”

While discussing the challenges and progress of times and of the public at whom analysis is directed, in "Lines of advance in psychoanalytic therapy" (1919 [1918]/1996c), Freud talked about the advancements of time and, consequently, about the need to adapt the psychoanalytic technique to those new conditions: "We will be faced, then, by the task of adapting our technique to such new conditions” (Freud, 1996c: p. 181).

This is the basis of our question: how to reflect on these recent changes and, in this case, while reckoning with increases in longevity and standard of living, how to reflect on aging in the perspective of psychoanalysis? According to Silva (2010), we are inserted in a culture, imbued with ideologies and theoretical assumptions about aging. How to think psychoanalysis based on what is signaled by both social and clinical practice changes? How do some theoretical presuppositions respond when facing the challenges presented by aging? In this sense, we highlight the challenge to distinguish what is the fruit of a historical moment, mutable, from what is understood as a concept which transcends those historical constructions. In other words, through a rereading of psychoanalytical theory, we need to review what is conjuncture and what is universal, or, how the universal fits into the conjuncture.

The demand coming from the aged calls for interdisciplinary contributions and interventions from different realms of knowledge. Following the Freudian perspective regarding the role of psychoanalysis in culture and pairing up with other sciences to deepen knowledge and seek relief for human pains, it is made necessary to join other fields of knowledge in order to broaden and sharpen the lenses through which we read, listen to and interpret the elders.

However, in order to establish a dialog, each field of knowledge must be distinctively delimited. Since this paper is based on Freudian Psychoanalysis, there must be a definition, or clarification, of what is understood as old age or aging within this field of knowledge.

By proposing this discussion, from the start we are dealing with the subject in two aspects: as the subject of 
the unconscious and as that of the social order. The latter refers to old age as a category arising from scientific discourses and from culture, constructed around the conception of a body in decline and one which marks the subject. The former conception-the subject of the unconscious - refers to those who attend our clinics in search of sustaining themselves as desiring subjects when facing a biological body which succumbs to the rigors of time. And, in the face of a body which declines, psychoanalysis comes forward as the one which/who listens, not to the biological body, but to the unconscious dimension within this finite body.

Psychoanalysis points to the subject's singularity and, moreover, to the subject who speaks and, while speaking, forges meanings to his/her history. Therefore, in this finite and fragile body, there is an interlocution point, which is (its) discourse. It happens through a subjective rectification, that is, subjects are summoned to realize what their participation is in their own suffering, what their involvement is as subjects in their own histories, in their own actions and ultimately, in their wishes. The wish belongs in unconscious. Thus, it is understood that such instance - the subject of the unconscious - must be the basis for approaching a clinic of aging; a required condition in order to go beyond the biological or cultural dimensions and other theoretical perspectives and anonymous conceptions relying on general notions suggested by the signifiers aging or agedness. Psychoanalysis' object of study - the unconscious - authorizes us to state that the analytical subject is the subject of the unconscious, and such does not age, as says Mucida (2006: p. 18):

In analysis, there is only one subject, the subject of the unconscious, and such does not age. As regards psych reality, there is not a difference between a past fact and a current one. The symptom signals the currentness of the past; what matters in the indication of analysis is the form by which the subject acts in the face of the lack of the Other and his/her relation with (the) wish, which is not determined by age let alone by the "quantity of psychic material", as conceived by Ferenzci. The concept of drive opposes any developmental notion; drive is always partial and adult sexuality is infantile sexuality.

In analysis, the subject is summoned to speak about his/her acts, which are marked by the unconscious and ultimately, stimulated by one's own wish. Hence, the question, "does it make sense to conceive of a psychoanalytic clinic of aging?” How to approach bodily changes brought about with time in psychic terms? In analysis, whether with children, adolescents, adults or elders, the subject under treatment is the subject of the unconscious, divided and symptomatic. We understand that referring to children's or elders' psychoanalysis, for example, results in an error, insofar as what actually exists is psychoanalysis, that which deals with the infantile, inherent to the subject of the unconscious, and which necessarily relates to the Other. Consequently, it can be asked: what will define or particularize psychoanalysis? When we refer to children's psychoanalysis, for example, are we alluding to methodology or to conduct? Or are we talking about the technical or operational tools which make analysis viable?

I therefore emphasize that the notion of a desiring/wishing subject is a concept which establishes and delimitates the field of psychoanalytic knowledge to the detriment of the anonymity and lack of complicity which the term aging or agedness evokes.

\section{Sublimation in the Clinic of Aging: Inventive Ways Out}

Once these fields have been circumscribed, it has to be questioned what it is that leads elderly people into analysis. Aging is the strange meeting of a weakening body with an ageless entity, the unconscious. A mismatch, actually, or a "misencounter"-failure to meet—which causes maladjustment or gives rise to feelings or emotions theretofore unfelt or unnoticed. Therefore, an aged body conflicts with a pulsional power that never ages. The latter wants more and more whereas the body no longer has the energy to match that demand. Whereas uneasiness is what leads the subject to analysis, here it is this maladjustment which convenes the subject to reposition himself/herself before his/her existence. A client under analysis refers to this moment by defining it in this way: "it's a getting-even moment"”. Another client adds: "it is necessary to re-exam one's history"”.

The psyche's function is to maintain the continuity of pleasure, of interest, of sense, of a constant flow of investment in oneself and also in one's body, in others, in activities, ideas and the external world. Capacity for investment is what sustains existence. Thus, [in analysis,] each one's possibilities are brought into consideration.

\footnotetext{
1“"é um] acerto de contas”-Brazilian idiomatic expression referring to "the instance of paying the bills", here meaning "issues that were not dealt with in the past and which resurface during agedness and demand that the subject face and elaborate them".

¿“[é preciso] passar a história a limpo”-another idiom, roughly "pass history clean”, meaning "rewrite history, from a scratch version into a corrected or perfected final version, by clarifying obscure parts”.
} 
Sublimatory vessels' must be sought even if "the I" (das Ich) is impacted by fragility. We believe that sublimation should constitute the founding and mobilizing axis in the psychoanalytic clinic of aging, since it is necessary to keep the investment flowing out of "the I" and its own body, even if losses have harmed both "the I" and the objects.

The function of sublimation firms up in the search for objects in reality, according to castration, the wish and pleasure. In "Anxiety and Instinctual Life—Lecture XXXII” ([1933-1932]/1996e: p. 99), while discussing the relation between drive and its target and object, Freud states that such relationship can change, by saying:

The relations of an instinct with its purpose and with its object are also susceptible to modifications; both purpose and object can be replaced with others although the instinct-object relationship is, nevertheless, the one which yields more easily. A certain type of change in purpose as well as a change of object, in which our social values are considered, is described as "sublimation".

It can then be said that, in sublimation, via symbolization, there is a constitution of new and different objects —related to primary ones—which are the source of creation. While referring to the target, Castiel (2007: p. 110) says: "we can say that a change in the target of the drive is related not to the search for direct and immediate satisfaction, but rather to all the settings required for the sublimatory fruition."

We can say that, in sublimation, there is a demand to change the object which, in its turn, will be a substitute for the sexual object. Here, we are referring to the plasticity of [the] drive. What makes the substitution possible is the fact that it is something socially accepted and valued, but still invested in with the subject's imaginary elaborations. The object changes, not the drive, since sublimation does not eliminate its sexual origin. The object suffers desexualization via displacement of the libidinal investment, which fell upon the sexual object at first and now is directed towards a non-sexual object.

Sublimation, as regards its concepts in psychoanalytic theory, arises in order to deal with the sexual origin behind the creative drive of the human being, and, by transforming the forces of sexual energy, sublimation converts them into productive and creative forces as mentioned previously. Sublimation then would be a means of attenuating such irruptive and violent sexual forces. As stated by Simões (2013: p. 6), "sublimating is finding satisfaction for the drive in another place than that of the symptom, or than that of the return of the repressed, or than that of the continuous signifying substitution".

In "Creative writers and day-dreaming" ([1908-1907]/1996f), Freud highlights the importance of creation and imagination in the sublimation process, while conceiving sublimation as a way to release the pulsional ${ }^{3}$ in the sense of pleasure. And here, Freud regards pleasure not as a total discharge of the drive (inertia), but rather as an alternative means of satisfying a wish and which also results in pleasure. In the sublimation act, there is the possibility of obtaining pleasure through the pulsive, indirectly, via a symbolical construction.

Also, according the "Creative writers and day-dreaming” ([1908-1907]/1996f), the unsatisfied subject, as regards the drive, creates other possibilities of satisfaction, via sublimation, transforming the sexual wish into something pleasurable, by means of a symbolical construction, thus avoiding giving up (on) the wish. Therefore, sublimation, as a psychic process, points to the fulfillment of the wish in another context and via other objects.

We can state that sublimation is connected to psychic anguish and pain as well as the elements internally perceived as dangerous, says Carvalho (2006). This means that the one who sublimates, as it were, needs to be in touch with the source of dangers in order for him/her to create, which implies that the subject is not protected by performing the act of sublimation, insofar as sublimation in itself "always bears a chance of failure in its endeavor, exposing something rather impossible” (Mucida, 2006: p. 90). In the face of helplessness each subject seeks to create, via sublimation, a unique form of existence and a personal way to inhabit his/her inner world. The only way to deal with abandonment is to keep on wishing, inventing a style, instead of seeking refuge in phallic ideals, although we know that there are other experiences which escape the rule when creative people cannot help developing symptoms or expressions of psychic suffering, something noticeable in several artists who succumb tragically.

We advocate the clinic of the elders as the clinic of sublimation in itself, that is, the clinic which believes in the idea of investment; building something which aids the subject in mingling in the network of relations, striking up and keeping bonds. The creation of new identity-signaling traits underpins the subject and enriches his/her subjectivity. The libido invested in new objects allows for the fading of the sadness and the pain.

\footnotetext{
$\overline{\text { 3“Pulsional” meaning the "driving force(s)", "trieb”. }}$
} 
Through this perspective, while talking about techniques to drive away psychic suffering in the footnotes of "Civilization and its discontents" ([1930-1929]/1988), Freud mentions a job as a powerful technique which anchors the subject in reality and assures him/her of a place in the human community.

The possibility this technique offers of displacing a large amount [sic] of libidinal components, whether narcissistic, aggressive, or even erotic, on to professional work and on to the human relations connected with it lends it a value by no means second to what it enjoys as something indispensable to the preservation and justification of existence in society (Freud, 1988: p. 87).

According to Birman (1997), by creating new senses, the psychoanalytic clinic brings ethics and aesthetics to the scene, that is, while regarding ethics, the subject faces his/her truth, wish and sexual impulses. Face to face with his/her own wish, what are the possible ways? It is a question of singularity, and the 'destination' each one gives his/her wish is what particularizes the being as a singular one. As regards the aesthetic perspective, in the face of the impossibility of fulfilling one's wish, the cure in psychoanalysis would consist in the transformation of the wish, as put by Castiel (2010: p. 6):

[...] I conceive of aesthetics as the capacity to give form to something. The direction of the cure relates to the idea that the subject can create out of the pulsional, constitute objects for the drives which will provide him/her with pleasure according to another context, reckoning with castration.

For instance, 80-year-old Namah, performs a construction during her analysis, in the fashion of a pendular movement, as put by Freud ([1937]/1996d: p. 254), alternating "between the id and the ego, analyzing now a fragment of the one and now of the other [...] our aim is to bring a part of the id into consciousness [...] to correct something in the ego.” At the age of 80 , getting into analysis was a new experience and just as new was the path she trod in her constructions and discoveries. While Namah retold her story, the analyst, as Freud ([1937]/ 1996d: p. 276) says, would "make out what has been forgotten from the traces which it has left behind or, more correctly, to construct it”. By becoming aware of the repetitions occurred during the transference, of the infantile contents being revised, as she got around the instances of resistance with difficulty, Namah moved along searching for alternatives which could help her in the contact with difficult and painful contents, but also with her potentialities. Lucidity, intelligence and cleverness were remarkable characteristics in this process. The fast thinking, the investigative character in what she calls "inventadeira de moda" ${ }^{4}$ contributed to her elaboration of grief, losses and, above all of looking ahead and, within her horizon, remaking her choices. The constructed project, that is, her discovery of herself as a writer, arisen during analysis, has constituted a meaning for life. Whereas previously she used to "look around at the walls"5 and wonder what to do, now this investment opens doors for other possibilities, such as the social realm. Writing has put her in contact with other writers and allowed for events in which recognition and appreciation are factors to boost self-esteem.

\section{Stories Told and Stories Lived: Particularities of the Clinic of Aging}

To the sublimation theme, we add the question of the urgency to weave the stories which tie us to life. "The I" is a historian; it is the one which confers sense upon past and future and chooses or builds an identification project based on its potentialities. However, such endeavor implies a changing "I" and, most importantly, imposes on itself the task to rethink, reorganize, and transform. The elderly person is challenged to reconsider his/her being, time and space, as well as to balance his/her past history and future projects. It depends on "the I" the task to integrate past and future.

The psychoanalytic clinic is a possibility of "looking back", reorganization time, one in which the elderly person can verify or build new meanings for existence. We can say that this constitutes one of the particularities of the psychoanalytic clinic of aging. In other words, it is the "time" in which to replace the previous reference axis with a new one. Where am I? What sense have I forged to my life? What have I done so far? (These) are the questions of this new "time". It is necessary to comprehend, get a hold and make use of this moment.

In the midst of an entanglement of ideas, memories, reminiscences and disconnections, it is required to gather patches from different times, from distinct experiences and make up a text. A text within one's possibilities,

\footnotetext{
4“inventadeira de moda”, roughly "fashion inventor" is a term coined by the client amusingly meaning someone who is restlessly trying new ideas or pulling a stunt, even unnecessarily taking risks, just for the sake of novelty or being bold or avant-garde.

5“olhar para as paredes”, roughly "keep looking at the walls” means staying home, in a room, feeling alone, bored and wondering what to do.
} 
sometimes spoken, sometimes written, sometimes said like a prayer; sometimes no text is possible, but only remembrances, mere recollections of facts. Regardless of the ways available, "recalling, repeating and elaborating" make up a great challenge.

The famous expressions we hear in our clinics "when I was a child" or "yesterday" or "tomorrow" concern a certain (period of) time, that of the consciousness. However, we hear them through the perspective of lapses, memories, formations of the unconscious, in which another (sense of) time surfaces, expressing an a temporal memory. Listening to the "underlying noise", to the recurring reminiscences: these constitute the essential, meaningful past in analysis; the past turned into psychic reality. A psych past which differs from a historical past and which does not become oxidized by linear temporality.

Time in psychoanalysis, therefore, is intensity time, amplified time, that of the reconstruction a posteriori. Intensity understood as experiences of pleasure and unpleasure/displeasure, felt and signified from the perspective of each subject's history, in which a minute can stand for eternity-time-timelessness outside the temporal logic, extensive and linear. In this dynamic, when we listen to the elderly person in the clinic, what or whom do we listen to? An aged body or singular psychic organizations? When hearing the words, who do we hear? The agedness or the pain which discomforts the analysand? By observing the manifestations of the unconscious, one will listen to the psychic dynamics or, rather, to the manifestations of such dynamics.

\section{Listening in the Psychoanalytic Clinic of Aging}

Every human being is unique, so is the psychic dynamic which sustains the constitutive identifications of "the I". Thus, in order to understand the approach each elderly person has come up with in his/her existence, it is necessary to trace the identity-signaling movements so as to find therein possible answers to the approach he/she has brought fourth. It is required to conjugate the anguish caused by the imminent losses and the need to get committed; but how to undertake adventures in this (period of) time which marks the body itself and brings along many social barriers? According to Soares (2011), upon perceiving the narrowing of the conditions, the elderly person presents different responses, including the refusal to accept the limitations, which can imprison him/her into a search for eternal youth with resorting to plastic surgery, for example. How to harmonize, in this body, an "I" that does not age, a fragile body, as regards energy, and a perfect body-image? The mental functioning made fragile, resorts to past images in search of experiencing something already gone and ends up losing its own references. Identity configuration becomes fragmented due to several factors such as function loss, internal and external motives and the impossibility of resorting to adaptive resources.

Aging is time to review one's history: history, identity and memory. In this movement, what is being spoken of is knowledge; wisdom which has been accumulated about oneself, facts and affections in life, as stated by Goldfarb (1997), "in order for my history to exist”, it is indispensable to recognize oneself as an individual in it, as a permanent subject. We know there are things which cannot change whereas others can so that an identity can be built.

Beyond an aging body, psychoanalysis puts in scene a "body traversed by the Other, traversed by the wish, by suffering; a body inhabited by a subject who has his/her own way of addressing the real” (Mucida, 2006: p. 25). Contrary to the parameters proposed by developmental psychology, according to Mucida (2006: p. 26), the concepts of the unconscious, drive, repetition and psychic reality show that the first marks imprinted on the subject by the Other never fade away and that they constitute a set working as a magnetic pole to the other traits. We should discard the notion that previous phases are completely supplanted as the subject goes through his/her developmental evolutive phases and reaches succeeding phases. Something is not translated from one phase to the other, said Mucida (2006: p. 26), “always being left behind as a mark which cannot be signified; this is what the real imposes on every speaking being".

We know that the subject gets constituted along a trajectory of identifications. And it is along this course of events that the subject recognizes him/herself, as he/she gets to know the other and vice-versa. And it is in this path that the psychoanalytical work of recognizing oneself in one's own wishes is accomplished. In old age, the subject faces a mutated, decadent body. The challenge is put forth, as stated previously: a conflict between ideal and real, between a narcissistic structure which has given support to the construction of an ideal body and the reality of body limitations. And, on the other hand, as stated by Freud, we do not have representations of death in the unconscious, since there where the wish dwells we believe ourselves to be immortal. Py (2006: p. 103) adds that "we do not know agedness before actually getting old. Agedness and death, however, are present in the 
narcissistic injury caused by frustration with illusions of eternity, beauty, potency and life itself”.

An analyst does not hold the function of making the symptom cease or providing cure, since, as we know, the subject lies in his/her symptom and where the subject is, there lies his/her wish. The symptom turns into mediation or into an opportunity for choice. The analyst's wish invites the subject upon the order of subject's wish, thus far like embers under ashes. By invoking the subject of the unconscious, the analyst always points to former's wish. Therefore, the analyst's wish is the function, via transference, which signals to the subject his/her condition of a divided subject, a prisoner of his/her wish. Thanks to the analyst's patient presence and, mainly with his/her bet, that is, investment in the possibility of transformation, means are gradually created in order for the analysand to develop, from within himself/herself, the capacity to be in contact with his/her inner world and, then, to make sense out of that which was left.

But, after all, who is the recipient of analytical work? Primarily, those who go through difficulties not only while facing a changing reality but also with the uneasiness and suffering coming from it, mainly when they throw themselves into trying to build a new way of life.

Clinically speaking, the individual who comes to us (for help) does it in order to keep his wish alive in the face of an extreme situation of existence in which there is a tendency towards passive self-denial, belying or resignation. The wish is ageless. Here the challenge consists in siding with life, even if the truth of the body frequently surfaces as a stage for infirmities or signals to death as an outcome. Upon this challenge, psychoanalysis summons the subject to the listening and the recalling, which enables one's own history and reconciles the subject with the legitimacy of his/her wish in a body that weakens day by day. As reminded by Fermán (2007: p. 83):

We are bodies, but also words; we are made of accounts of stories which inhabit us and constitute us from the moment we are born till we die. We are bodies and narrative. In this way, we are construction and constructors. Therefore, it is always possible to write, reformulate identifications that cause suffering to either the subject or to (the) others (Translation ours) ${ }^{6}$

The analytical space constitutes itself, then, as space of words and affection aiming at modifying the sterility of the symptom and inviting the elderly person to take over his/her own condition as a human being or, better, as a wishing subject. Analysis makes it possible to dismantle crystallized images of agedness of those who seek us as well as to invite the subject to take responsibility for the fate of his/her actions, having the very wish as their most legitimate motive. The analysis can be found rather in one's personal attitude and will than in the chronological age of those who consult.

As says Dayrell (1997: p. 102), "the analyst listens to the stumbles in discourse because therein lies the subject”. The analysand does not recognize himself/herself in his/her stumbles which seem to be awareness without a Subject. However, as he/she speaks, out of it a Subject may emerge. If the elderly person speaks of his/her symptom, therein lies a truth, one which has built a way. It is up to the analysis to return the analysand to his/her own history, reestablish him/her where he/she should wish, his/her unconscious structure.

The work with the elderly person in particular requires a distinct perspective or, better, a distinct listening. Due to the state of vulnerability some of them are in, it is necessary to interpret or comment only when the analysand is able to put up with the impact of it; otherwise, a "side effect" will be produced. In fact, management includes welcoming and intervening empathetically while aiming at the elaboration of the crisis; handling anguish until the moment transference bonds are created which will allow for the beginning of the analysis itself. One can conceive of an affective support in which some elements can be taken into account such as the strengthening of the ego, protection of the defenses, handling inferiority feelings, self-image and life reviewing. On the other hand, there is the risk of withdrawing due to the elderly person's fragility, which results in loss, insofar as the subject must handle his/her symptom and devise ways out of his/her uneasiness. Mucida (2014: p. 104) signals that:

[...] the analyst must know the limits of his/her interventions by not ignoring the effectiveness of the organic and the uses of one's own body fragility as a means of jouissance. In spite of diseases and the limitations some pathologies impose on old age, the analyst can only operate with the discourse and the affections

${ }^{6}$ Por cierto que estamos hechos de cuerpo, pero también de palabras, de relatos, historias que nos habitan y constituyen desde que nacemos hasta que morimos. Somos cuerpo y narración. Desde ésta óptica, somos construcciones y constructores. En este sentido siempre es posible re escribir, re formular identificaciones que hacen padecer al sujeto o a los demás. 
which impact the body. The analytical discourse does not treat possible disabilities (visual, hearing, motor impairments) or the pathology of aging, but it can listen to their consequences in view of the libidinal body and the affections present in the mystery of the speaking body.

Confrontations with losses and at the same time the weakening of defense mechanisms can be great allies in the analytical alliance, because they tend to reduce resistance. The clinic of aging has been the space to deconstruct some prejudices, mainly the one linking rigidity to aging. Rigidity and flexibility are not factors associated with age groups, but rather originating in or determined by the nature of the personality constructed along the subject's history.

In the work with the elderly, and not only there, I remember a biblical verse from prophet Isaiah's book, "he does not $[\ldots]$ snuff the faltering wick" (Is, 42, 3). With the elders, emphasis must be placed on the powers, resources and potentialities. The positivity of the subject's history must be pointed out, each moment must be valued and the subject must always be involved in the construction of his/her existence. Sometimes we can count on the elders' capacity of resilience; because of painful experiences in life, they turn losses into a springboard so as to reconcile themselves with their history and projects; they forge possibilities of real cure for themselves, by actively solving their problems and becoming open to new learning. The elders are capable of learning anew, however, within their own context and in a less intense pace when compared to young people.

In this construction process, most of the times, the analyst is the elder's only ally and constitutes the most important person in his/her life, mainly if the elder's social circle has become too small. It is common to hear and make statements such as, "you can't imagine how difficult it has been to wait until this session" or "I thank God every day for having met you... here I can talk about these things... and somebody will listen to me... only here I can say these things".

\section{The Clinic of Aging in Everyday Life}

Freud ([1933-1932]/1996g: p. 82) says "life is not easy". It is commonplace to hear the elderly repeating the same phrase. The "it-is-not-easy" can be understood as an expression of the symptom which is translated into the manner of the subject's enjoyment. And as the story is being told, meandering along, there emerges a subject with his/her conflicts and demands. Listening to the story gradually signals to the analyst the origin of the conflict and the psychic instances in which the pulsional movements are processed. Hence, the attentive listening based on the economic, topic and dynamic dimensions.

The psychoanalysis comes forth as a possibility of comprehending aging as well as an intervention tool which eases the elaboration and construction of meaning in the face of the ego's different tasks in this phase of life. The ego's and the libido's development is a process running throughout a subject's existence, in each period, demanding different functions. In each period, there are aspects the subject needs to deal with, whether it is marriage, parenthood, retirement or death. And through this very perspective, Freud ([1933-1932]/1996g: p. 84) reminds us, in Lecture XXXI, that the purpose of analysis is a construction when he says:

Its purpose is, indeed, to strengthen the ego, to make it more independent of the super-ego, to widen its field of perception and enlarge its organization, so that it can appropriate fresh portions of the id. Where the id was, the ego shall be. It is a work of culture - not unlike the draining of the Zuider Zee.

The work with the elderly in the psychoanalytical clinic presents some particularities, which requires that the psychoanalyst make changes to the treatment management. Given the health, memory and dementia conditions of certain analysands, special abilities and knowledge are fundamental to conduct the analysis. The interdisciplinary work is the best response. One cannot simply interpret forgetting or a lapse in the speech of an elderly individual as a manifestation of the unconscious; it might as well be due to a lesion in the hippocampus ${ }^{7}$, for example. The partnership with geriatrists has been highly valuable. When a client presents some disorder in this area, it is appropriate to request a professional opinion, which aids greatly in guiding the process as well as in changing the approach.

The work with the elderly is complex since it involves several factors that touch on issues concerning personal life, generational groups, family life, beliefs, religion, physical diseases, dreams, a reduction both in cognitive

${ }^{7}$ The hippocampus is situated in the limbic system; it is bilateral and has several functions, the main of which is forming and evoking memories and/or inducing the rest of the cerebral cortex to do the same. The hippocampus and its connections are the main regions in the brain involved in the formation and evocation of memory (Colunista Portal_Educação, 2012). 
and sensorial abilities and medication (side) effects. The combination of these elements makes the clinic of aging a challenging construction which requires that the analyst be skillful and flexible, not to mention supervision from another analyst who also attends to elderly people, as there are blind spots which make this kind of analysis difficult as any other. Here, it is called complex due to the tendency many psychoanalysts have to isolate themselves in their spaces and fail to be open to discussing this issue with another professional.

Depending upon the elderly person and the demand presented with, processes must be made flexible. There may be situations in which the place used for analysis has to change; sometimes the analysand should be seen at his/her home, with due attention to protection and the confidentiality of the session. It is not always possible to find suitable places in which privacy can be guaranteed. In such cases, the contract must be clear regarding what can or not be shared with the team of caretakers, even under family pressure. It shall be limited to what is strictly necessary for the care with the elderly person. This will respect the subject's right to privacy. However, contents not involving confidentiality and important to the whole team must be brought into discussion. According to the setting, special care must be offered the family, such as affective and emotional support; it is also important to coordinate and educate the team of caretakers.

In the office itself there is a need for changes such as noise reduction, light balancing (eliminating excesses or shortages), speaking lower and more slowly, getting closer to the analysand, other times, speaking louder. In order for the client to sit down or stand up, out of precaution, the analyst should be available to be of help, offering an arm for support, if necessary. And, as previously mentioned, during the analysis, priority may consist in paying more attention to something which is "crying out loud" at the moment, that is, the suffering. Indeed, listening... listening...

Session duration may be adjusted to less than or over fifty minutes, at first. The objectives of the analysis must be defined, especially to the family, clarifying and adjusting expectations. The client's family should be included in the process of analysis, when convenient, as long as it is not forgotten that analysis should reinforce the individual's independence, whenever possible.

Broadly speaking, working with the elderly requires more time, not strictly devoted to the analysand. The analyst's work goes beyond that in the office, as it tends to be a network operation involving other professionals, as previously advocated. As regards the analysand under prescribed medication, sound knowledge must be obtained about the medication and its side effects since it will aid in monitoring him/her. I further highlight the partnership with other fields of knowledge in order to facilitate or clarify anything elusive to the analyst's specific expertise. Another possibility consists in an alliance with other professionals such as nurses, social assistants, religious leaders, lawyers, so as to build an interdisciplinary team, mainly in the sphere of publicly funded (health care) services. If the service is private, counting on at least some of these professionals is very valuable, depending on the situation.

\section{Conclusion}

Analysis with the elderly does not differ from analysis with an adult while regarding the subject matter, which is the unconscious. We are before a subject who speaks and, by speaking, searches for his/her own resources so as to come to terms with what frightens and ails him/her. The most important factor which determines the case for analysis is not age but the means provided by the analysand for the analytic process to occur and be sustained. We can surely state that there is not a symptom specifically of the elderly; we frequently hear "this is an old person’s habit” which is probably nothing else than prejudice. As put by Mucida (2014: p. 58):

[...] symptoms for psychoanalysis are not pathologies, but responses and attempts to dealing with the Real. Therefore, they cannot be eradicated, but analyzed. If, in old age, the symptoms tend to be read and interpreted as pathologies, the tendency to illness perseveres.

The clinic of aging presents some inescapable evidence. There are, indeed, losses and changes affecting the body and, unlike those in adolescence which widen one's horizon, in old age they reduce possibilities in every way. The same can be said in regard to the symbolic resources, in which changes in social relations tend to hinder possibilities of sublimatory outlets. Despite all significant changes, there is not only one way to become old, since each person follows his/her own course and history. The body can bring the marks of time, but the subject of psychoanalysis moves indelible across time, because such - the unconscious - does not age, as has been so well described by Freud ([1915]/1996h: pp. 191-192) when he said, “and are also timeless; i.e., they are 
not ordered temporally, are not altered by the passage of time; they have no reference to time at all”.

In the face of scarce literature on the field, this paper features beneficial novelty, while we also acknowledge its critical relevance due to how this knowledge has been systematized and advanced with the support of clinical listening, all of which concur to prove the viability of analysis for the elderly. Besides, this study called for a re-reading of Freud on what was, inside his work, the fruit of the culture of his time, and then updating it. Freud's very text authorizes and invites us to always open ourselves to new challenges. The rapid increase of the elderly population, along its demands, is thereby a great challenge we have been faced with in contemporaneity, properly dealt with here.

At the end of this paper, we can remember Freud in Lecture XVII ([1916-1917]/2014: p. 343), discussing about the formation of the symptom when he says: "every discovery is made more than once, [...] none is made all at once". The psychoanalytical clinic of aging, constitutes not a discovery, but a re-thinking of the theory taking into account the challenge of aging with its specificities and the analysis management.

\section{References}

Berquó, E. S. (1996). Algumas considerações demográficas sobre o envelhecimento da população do Brasil. Anais do Seminário internacional envelhecimento populacional: Uma agenda para o final do século, 1. Brasília: MPAS.

Birman, J. (1997). Estilo e modernidade em psicanálise. São Paulo: Editora 34.

Castiel, S. V. (2007). Sublimação: clínica e metapsicologia [Sublimation: Clinic and Metapsychology]. São Paulo: Escuta.

Castiel, S. V. (2010). Sublimação e clínica psicanalítica [Sublimation and Psychoanalytical Clinic]. Psico, 30, 22-31. http://dx.doi.org/10.1590/s1414-98932010000100003

Carvalho, A. C. (2006). Limites da sublimação na criação literária [Limits of Sublimation in Literary Creation] [S.l.]. CBC. http://www.cbp.org.br/rev2915.htm

Colunista Portal_Educação (2012). Que estruturas cerebrais estão envolvidas nos mecanismos de memória? [S.l.]. Portal Educação, 16 Nov.

http://www.portaleducacao.com.br/psicologia/artigos/21575/que-estruturas-cerebrais-estao-envolvidas-nos-mecanismos-d e-memoria

Dayrell, M. Â. A. (1997). Pulsão, seus destinos e final de análise [(The) Drive, Its Fate and the End of Analysis]. Texto apresentado no CPMG—Seminário sobre o texto freudiano, 23 out [Paper presented during CPMG—Seminar on the Freudian text].

Fermán, A. F. (2007). El psicoanálisis com adultos mayores: Subjetividade, relato y vejez. Revista Brasileira de Ciências do Envelhecimento Humano [Brazilian Journal of Human Aging Sciences], 4, 76-87.

Freud, S. (1988). O mal-estar na civilização [Civilization and its discontents] (1930[1929). In Edição standard brasileira das obras psicológicas completas de Sigmund Freud [Brazilian Standard Edition of Sigmund Freud's Collected Psychological works] (pp. 65-148). Rio de Janeiro: Imago.

Freud, S. (1996a). O método psicanalítico de Freud [Freud’s Psychoanalytical Method] (1904[1903]). In Edição standard brasileira das obras psicológicas completas de Sigmund Freud [Brazilian Standard Edition of Sigmund Freud's Collected Psychological Works] (Vol. 7). Rio de Janeiro: Imago.

Freud, S. (1996b). Sobre a psicoterapia [On Psychotherapy] (1905[1904]). In Edição standard brasileira das obras psicológicas completas de Sigmund Freud [Brazilian Standard Edition of Sigmund Freud's Collected Psychological Works] (Vol. 7). Rio de Janeiro: Imago.

Freud, S. (1996c). Linhas de progresso na terapia analítica [Lines of Advance in Psychoanalytic Therapy] (1919[1918]). In Edição standard brasileira das obras psicológicas completas de Sigmund Freud [Brazilian Standard Edition of Sigmund Freud's Collected Psychological Works] (Vol. 17). Rio de Janeiro: Imago.

Freud, S. (1996d). Análise terminável e interminável [Analysis terminable and interminable] (1937). In Edição standard brasileira das obras psicológicas completas de Sigmund Freud [Brazilian standard edition of Sigmund Freud's collected psychological works] (pp. 223-270). Rio de Janeiro: Imago.

Freud, S. (1996e). Conferência XXXII [Lecture XXXII] In: S. Freud (Ed.), Novas conferências introdutórias sobre a psicanálise [New Introductory Lectures on Psychoanalysis] (Vol. 14, pp. 85-112). Rio de Janeiro: Imago.

Freud, S. (1996f). Gradiva de Jensen escritores criativos e devaneio. [Gradiva de Jensen, Creative Writers and Day-Dreaming] (1908[1907]). In Edição standard brasileira das obras psicológicas completas de Sigmund Freud [Brazilian Standard Edition of Sigmund Freud's Collected Psychological Works] (pp. 135-143). Rio de Janeiro: Imago.

Freud, S. (1996g). Conferência XXXI [Lecture XXXI] (1933 [1932]). In Edição standard brasileira das obras psicológicas completas de Sigmund Freud [Brazilian Standard Edition of Sigmund Freud's Collected Psychological Works] (Vol. 22). Rio de Janeiro: Imago. 
Freud, S. (1996h). O Inconsciente [The Unconscious] (1915). In Edição standard brasileira das obras psicológicas completas de Sigmund Freud [Brazilian Standard Edition of Sigmund Freud's Collected Psychological Works] (Vol. 14). Rio de Janeiro: Imago.

Freud, S. (2010). Princípios básicos da psicanálise [Basic Tenets of Psychoanalysis] (1913). São Paulo: Companhia das Letras.

Freud, S. (2014). Conferência XXVII: A Transferência [Lecture XXVII: Transference] (1916 [1917]). São Paulo: Companhia das Letras.

Goldfarb, D. C. (1997). Corpo, tempo e envelhecimento [Body, Time and Aging]. Dissertação de Mestrado [Master’s Thesis on Clinic Psychology], São Paulo: Pontifícia Universidade Católica de São Paulo.

Mucida, Â. (2006). O sujeito não envelhece: Psicanálise e Velhice [The Subject Does Not Age: Psychoanalysis and Agedness]. Belo Horizonte: Autêntica.

Mucida, Â. (2014). Atendimento de idosos [Assisting the Elderly]. São Paulo: Zagodoni.

Py, L. (2006). Envelhecendo e Subjetividade [Aging and Subjectivity]. In L. Py et al. (Eds.), Tempo de envelhecer: percursos e dimensões psicossociais [Time to Age: Paths and Psychosocial Dimensions] (2nd ed., pp. 97-120). Holambra: Setembro.

Silva, J. M. (2010). O lugar do pai: Uma Construção Imaginária [The Place of the Father: An Imaginary Construction]. São Paulo: Annablume.

Simões, R. B. F. (2013). As Vicissitudes do Amor: Narcisismo e Sublimação [Love’s Vicissitudes: Narcissism and Sublimation]. Revista Psicologia Para América Latina [Psychology for Latin America Magazine], 22, 1-5. http://www.psicolatina.org/09/vicissitudes.html

Soares, S. S. G. S. (2011). O processo de Envelhecimento e as Mudanças no Edifício da Identificação [The Aging Process and Changes in the Identification Edifice]. São Paulo: Estados Gerais da Psicanálise.

www.estadosgerais.org/atividades_atuais/processo_de_envelhecimento.shtml

\section{Submit or recommend next manuscript to SCIRP and we will provide best service for you:}

Accepting pre-submission inquiries through Email, Facebook, Linkedin, Twitter, etc A wide selection of journals (inclusive of 9 subjects, more than 200 journals)

Providing a 24-hour high-quality service

User-friendly online submission system

Fair and swift peer-review system

Efficient typesetting and proofreading procedure

Display of the result of downloads and visits, as well as the number of cited articles

Maximum dissemination of your research work

Submit your manuscript at: http://papersubmission.scirp.org/ 